Terbit online pada laman web jurnal : http://e-journal.sastra-unes.com/index.php/JIPS

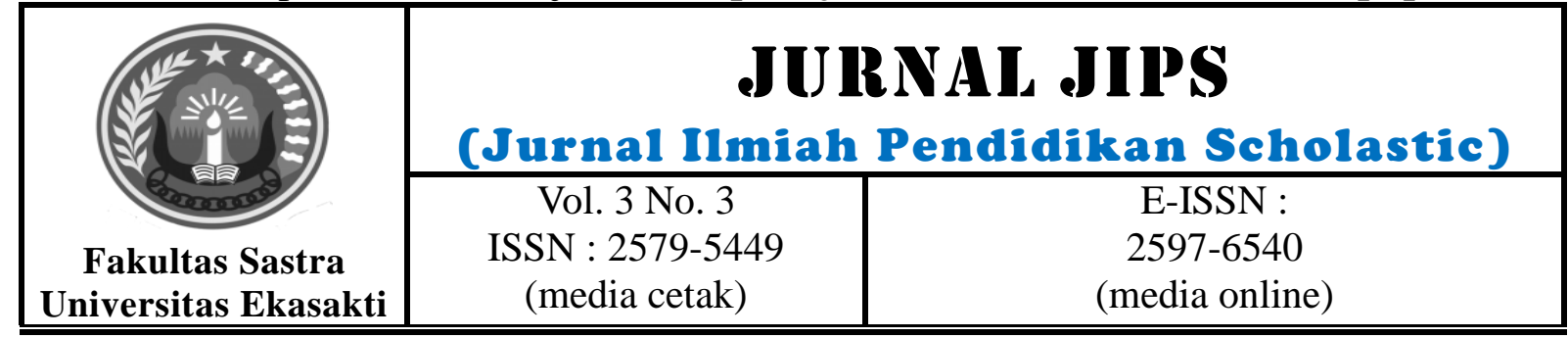

\title{
THE CORRELATION BETWEEN STUDENTS MOTIVATION AND THEIR SPEAKING SKILL AT MAN 2 PADANG
}

\author{
Raflis, Yolanda Gustari \\ Fakultas Sastra Universitas Ekasakti, raflisdrs@gmail.com, Fakultas Tarbiyah Dan Keguruan, UIN Imam Bonjol Padang \\ *Corresponding Author: Yolanda Gustari \\ Fakultas Tarbiyah Dan Keguruan, UIN Imam Bonjol Padang
}

\begin{abstract}
This research aims to see whether or not there is a positive correlation between students' motivation and speaking skills. The population of this research is students of class X man 2 Padang in the 2028/2019 school year. Total students of all are 315 students. In determining the sample, researchers used cluster sampling techniques by taking two normal and homogeneous classes. In this study the total sample was 59 students. In collecting data, researchers used questionnaires and documents. Questionnaire to see student motivation used by students in TALK and documents to measure students' Speaking comprehension. In analyzing data, researchers used the product moment formula. After analyzing the data, the researchers found the value of the cognitive strategy t-test was 0.32 with a significant level of 0.05 . The results of the $t$-table are 0.256 with a significant level of 0.05 and degree of freedom $(d f=n$-2). This means that the $t$-count is higher than the $t$-table $(0.32>0.256)$. This means that the t-test is higher than the t-table so the hypothesis in this study is accepted. Based on this research it can be concluded that motivation in speaking ability influences students' speaking comprehension.
\end{abstract}

Keywords: Motivation, Speaking Skill

C 2019Jurnal JIPS

\section{INTRODUCTION}

English is a language used in all aspects of communication, science, and technology. english has two ways of communicates, there are oral and written communication. english has four essential skills that should be improved by the learners. there are; reading, writing, listening and speaking. as the other skills, speaking is an important skill that has to be mastered by student in learning english. according to (scott thornbury:2003) speaking is interactive and requires the ability to co-operate the management of speaking turn. it also typically takes place in real time, with little time for detailed planning . speaking has to be developed by someone who wants to acquire a language well. it is the way for people and especially students to share what their ideas, opinions, feelings and thoughts. as a way to communicates, speaking has an important role for student to learn english well. it showed how much the learners comprehend and master in learning english. speaking included all other skills of knowing that language it's an art of communications and one of four productive skills, that must mastered in learning foreign language. 
In learning english especially speaking, there are some factors that affect the student speaking achievement, one of them is motivation. according to (jeremy harmer : 2007) motivation is some kind of internal drive which pushes someone to do things in order to achieve something. it means that, motivation is a force to encourage or provide direction to students so that students can easily achieve the goals of their learning. beside that there are two types of motivation such as intrinsic motivation and extrinsic motivation.

in indonesia, english is still thought as a foreign language ( efl). some of students feel that english is not really important because they do not used english in their daily life but just for certain need. for instance, they used english in speaking class, when they speak to their teacher or when they communicate with foreigners. because, the students just used english as foreign language it makes them keep silent or even scared to speak english. they cannot express their ideas orally. they fear of making mistakes, fear of being laughed at their friends, having less confidences of their own ability and they have less of curiosity for studied or doing their activity. however learning speaking is more effective if the learners are actively involved in the process of learning. for this situation, the researcher believe that motivation can support the student in learning and also it has a positive effect for the students.

relating to that statement, the researcher intended to study more about the correlation between students' motivation in their speaking skill at man kota solok in academic year of 2019/2020. here, according to the writer's observation during ppl while teaching learning speaking process, the researcher find out that most of the student always keep silent and scare of making a mistake in speaking performance. they can not share their ideas or answer the questions that the teacher give to them. they usually used their mother tongue to share their opinion or answer the question that the teacher ask about their lesson, less of curiosity, they do not enjoy the process and pay attention while the learning process. they like to make a noise, disturb their friends. therefore, the researcher assumed that students with higher motivation in learning english speaking were supposed to be more active than those with lower motivation. in the context with learning activities, motivation becomes the activator to achieve the desired goal and the researcher believes without motivation, learning objectives will not be achieved.

The starting point in a successful learning is student's motivation because it can be a stimulus for them. this stimulus, bring a pleasure to the students to learn the lesson and build their spirit. based on that reason, the researcher is interested to conduct research on title "the correlation between students' motivation and their speaking skill"

There are some theories that are explained by experts about definition of speaking The researcher uses Nunan and sccott turnburry In conclusion, conversation/dialog between two people to express orally any massage of information. The researcher use some theories about motivation they are jeremy harmer, and schunk Based on the some definitions above, it can be concluded

Motivation is an essential of learning to achieve something. It is a process which directs students to activity to get goals. James says that the idea of someone to conduct activity and control the frequency of the actions is called motivation. It gives a great influence to students to push them selves in learning to get their needs, goals, and interests. From those definitions above, it is concluded that motivation is an energy and direction to do something. Motivation is a process to get success and has a great influence to the future achievement. In teaching and learning process, giving motivation to the students is a process to push and to support them to learn. Therefore, it can help the students to achieve their goals. motivation divided into two part, they are : extrinsic motivationn and instrinsic motivation

The emphasis of the discussion in this section is in the form of references from journals or previous research according to the research topic, avoiding unimportant theories and non-urgent definitions in the research discussion.

Motivation is an essential of learning to achieve something. It is a process which directs students to activity to get goals. James says that the idea of someone to conduct activity and control the frequency of the actions is called motivation. It gives a great influence to students to push them selves in learning to get their needs, 
goals, and interests. From those definitions above, it is concluded that motivation is an energy and direction to do something. Motivation is a process to get success and has a great influence to the future achievement. In teaching and learning process, giving motivation to the students is a process to push and to support them to learn. Therefore, it can help the students to achieve their goals.

\section{RESEARCH METHOD}

The data were the students' motivation questionnaire and speaking final score that given by teacher who thought at tenth grade students of MAN 2 Padang. There were thirteen classes at tenth grade students of MAN 2 Padang with total of students 315 students. In this research, the researcher took the data by using cluster sampling. According to Gay and Airisian (2012:135) state that Cluster sampling may be the only feasible method of selecting a sample when the researcher is unable to obtain a list of all members of the population. Then, researcher got two classes that have normality and homegenity as the sample. The total sample in this research was 59 students.

In collecting the data for this research, the researcher did several steps, first the researcher gave the questionnaire to the sample. Then, the researcher analized it. Next, the researcher collected the speaking final score from the teacher who taught the sample at tenth grade students of MAN 2 Padang.

After collecting the data, the researcher analyzed it. There were two kinds of the instruments that were analyzed; students' motivation questionnaire and teacher made speaking test. First, the data was analyzed by scoring the students' Motivation questionnaire. The result of questionnaire was found by sum up the total respon's score from the questionnaire. The students' score of questionnaire is calculated by using formula (Riduwan, 2005):

Where:

$$
\mathrm{P}=\frac{F}{N} \mathrm{x} 100
$$

$\mathrm{P}$ : Percentage of students score

F : Sum of students score

$\mathrm{N}$ : score maximum

After knowing the maximum score, then find the mean score by first making helper table. After making the table data showed that: $\Sigma \mathrm{x}$ and Then the next step is to find the mean of the variable $X$, as cognitive strategies, while to find the mean for the variable $\mathrm{X}$ use calculate such as

$$
\mathrm{X}=\underset{\mathrm{Xi}}{\mathrm{N}}
$$

Where:

$\mathrm{X}=$ Mean

$\Sigma x i=$ All Score variable $\mathrm{X}$

$\mathrm{N}=$ sum of sample

After the score of questionnaire and score have been known, the researcher analyzed them by product moment correlation to know the correlation between motivation and speaking comprehension (Sugiyono,2013:248). To find the value of the correlation between variables $X$ and $\mathrm{Y}$ variables and also find out whether the relationship of the variables including both close links, simply, is weak, then the author using the formula ' $\mathrm{r}$ ' product moment as follows:

Where:

$\mathrm{r}=$ Correlation coefficient

$\Sigma \mathrm{X}=$ The values for the $\mathrm{X}$ variable

Where:

$$
r=\frac{\sqrt{\sum \mathrm{xy}^{2}}}{(\mathrm{x} 2)(\mathrm{y} 2)}
$$

$\mathrm{r}=$ Correlation coefficient

$\Sigma \mathrm{X}=$ The values for the $\mathrm{X}$ variable 4

$=$ The values for the $\mathrm{Y}$ variable

value of $X Y$ variable

In this research, there were two hypothesis as follow:

H1 : There was a correlation between students' cognitive strategies and their reading comprehension at tenth grade students of MAN 2 Padang at academic year 2018 / 2019

H0 : There was no correlation between students' cognitive strategies and their speaking comprehension at tenth grade students of $\mathrm{S}$ MAN 2 Padang at academic year 2018 / 2019

The result of correlation between $\mathrm{X}$ and $\mathrm{Y}$ variables compared with the value (r-table). The table value is $5 \%$ or $1 \%$. If rxy> r-table is significant. There is a correlation between students' Motivation and their speaking comprehension. If rxy $<\mathrm{r}$-table is not significant. 
It means that there is no correlation between students' Motivation and their speaking comprehension.

Finally, in order determining the strength of the correlation, the researcher used general coefficient correlation that suggested by Arikunto (2002:245) the explanation is as follow:

\section{RESULTS AND DISCUSSION}

To find the correlation students' Motivation and their speaking comprehension. there were two kind of the instruments that were used by the researcher. They were questionnaire and teacher speaking made test.

The researcher find out the score of questionnaire $(\mathrm{X})$ and the score of speaking comprehension $(\mathrm{Y})$ of the sample class. The total score of questionnaire $(\Sigma \mathrm{x})$ is 4.432 and the total score of reading comprehension score $(\Sigma y)$ is 4.181. Next, the researcher find the total score of cross product $\mathrm{XY}(\Sigma \mathrm{xy})$ is 28.555 . Thus, the researcher found the total $\mathrm{X} 2(\Sigma)$ is 25.573. Last,the total of Y2 ( $\Sigma$. After getting the result of each variable the researcher used PearsonProduct Moment $(r)$ formula find out the correlation between students' Motivation and their speaking comprehension.and $r$ - calculated was $(0,32)$.

The Calculation of Coefficient Correlation Pearson Product Moment of Students' Cognitive
Table 3.1 The Strength Of The Coefficient Correlation Coefficient Correlation

$0.00-0.20$

$0.21-0.40$

$0.41-0.60$

$0.61-0.80$

$0.81-1.00$
Criterion

Very low

correlation

Low correlation

Moderate

correlation

High

correlation

Very high

correlation

Strategies $(\mathrm{X})$ and Their Reading Comprehension(Y)

After the researcher calculate the data by using $r$-calculate, it found $r$-calculate is higher than $r$-table. In the degree of freedom $(d f) \mathrm{n}-2$ where the level of significant (a) 0,05 is 0,256 , so hypothesis is accepted. Based on the data analysis above, the researcher found that $t$ calculated is $(0,32)$ and $t$-table in the degrees of freedom $(d f) \mathrm{n}-2$ where the level of significance (a) 0,05 . It clearly showed that $t$-calculate is higher than $t$-table. Then, the strength of its correlation is resided in low correlation. After the researcher calculate the data by using PearsonProduct Moment $(r)$ formula, $r$-calculate higher than $\mathrm{r} t$-table, so H1 is accepted. Therefore, the relationship students' Motivation and their speaking comprehension.

As overall, it can be concluded that students' motivation give the little improvement to speaking skill.

\section{CONCLUSION}

The researcher do a research to find out whether there is correlation between students' motivation and rspeaking silll $\mathrm{c}$ at tenth grade at MAN 2 Padang. This research is correlation research. In this research, the researcher use two kinds of the instrument, they are questionnaire and teacher speaking made test. Questionnaire is used in order to get the deeper information about the students' motivation. There are 14 items of students' motivation questionnaire and teacher

speaking made test to know speaking comprehension students.

Based on finding as already discussed in the previous chapter, the researcher point out the conclusions. First, there is a positive correlation between students' motivation and speaking skill of tenth grade students at MAN 2 Padang. It is proved by the valued of $t$-calculate which is higher than $t$-table. Second, the researcher found the coefficient correlation or $t$ calculate 0.32 and 
t-table 0.256. It can be viewed from the statement of the questionnaires. In conclusion, there is positive correlation between cognitive strategies and reading comprehension of tenth grade students at MAN 2 Padang. The correlation is categorized as low correlation

Therefore, the researcher the researcher propose several suggestion. First, the English teacher would get information about the correlation between students' motivation and their speaking skill. Therefore, English teacher are expected in support the students to improve their strategies in speaking in order to have a good speaking comprehension. They have to increase another strategies in r speaking by using some books and texts that interesting for them. 


\section{Bibliography}

[1]Arikunto, Suharsimi. 2010. Prosedur Penelitian. Suatu Pendekatan Praktik. Jakarta: Rineka Cipta.

----------(Ed).2002. Prosedur Penelitian: Suatu Pendekatan Praktek.Jakarta: Rineka Cipta.

[2]Ary et al. 2010. Introduction To Reasearch In Education.8th Ed. New York: Nelson Education.
[3]Brown, Douglas. H. 2004. Language Assessment Principle and Classroom Practice. San Francisco: Longman. dengan Menggunakan Minitab. Padang:UNP

[4]Thornburry, Scott. 2000. How to teach speaking. London : Longman

[5]Harmer, Jeremy. 1991. The Practice of English Language Teaching. $4^{\text {th }} \mathrm{Ed}$. London: Longman 